\title{
TREE-RING RESPONSE TO SNOW COVER AND RECONSTRUCTION OF CENTURY ANNUAL MAXIMUM SNOW DEPTH FOR NORTHERN TIANSHAN MOUNTAINS, CHINA
}

\author{
LI QIN, YUJIANG YUAN, RUIBO ZHANG, WENSHOU WEI, SHULONG YU, ZIANG FAN, FENG CHEN, \\ TONGWEN ZHANG and HUAMING SHANG \\ Institute of Desert and Meteorology, China Meteorological Administration / Xinjiang Laboratory of Tree Ring Ecology / Key Labora-
} tory of Tree-ring Physical Chemical Research, China Meteorological Administration, No. 46 Jianguo Road, Urumqi 830002, China.

Received 25 August 2015

Accepted 1 December 2015

\begin{abstract}
Heavy snowfall and extreme snow depth cause serious losses of human life and property in the northern Tianshan Mountains almost every winter. Snow cover is an important indicator of climate change. In this study, we developed five tree-ring-width chronologies of Schrenk spruce (Picea schrenkiana Fisch. et Mey) from the northern Tianshan Mountains using standard dendrochronological methods. Correlation analyses indicated that radial growth of trees in the northern Tianshan Mountains is positively affected by annual maximum snow depth. This relationship was validated and models of annual maximum snow depth back to the $18^{\text {th }}$ century were developed. The reconstruction explains $48.3 \%$ of the variance in the instrumental temperature records during the 1958/59-2003/04 calibration periods. It indicates that quasi-periodic changes exist on 2.0-4.0-yr, 5.3-yr, 14.0-yr, and 36.0 -yr scales. The reconstructed series shows that maximum snow depth exhibits obvious stages change, the periods characterized by lower maximum snow depth were 1809/10-1840/41, 1873/741893/94, 1909/10-1929/30, 1964/65-1981/82, and the periods characterized by higher maximum snow depth were 1841/42-1872/73, 1894/95-1908/09, 1930/31-1963/64, and 1982/83-present. The lower period of annual maximum snow depth during the 1920s-1930s is consistent with the severe drought that occurred at this time in northern China. From the 1970s to the present, the maximum snow depth has increased clearly with the change to a warmer and wetter climate in Xinjiang. The reconstruction sheds new light on snow cover variability and change in a region where the climate history for the past several centuries is poorly understood.
\end{abstract}

Keywords: Northern Tianshan Mountains, cliamte change, maximum snow depth reconstruction, tree-ring, Schrenk spruce (Picea schrenkiana Fisch. et Mey).

\section{INTRODUCTION}

Mountain snow cover is an important water source for arid areas. However, large amounts of snow can lead to destructive avalanches, floods, traffic interruptions, or

Corresponding author: R.B. Zhang

e-mail: river0511@163.com even the collapse of buildings (Marty and Blanchet, 2012). The Tianshan Mountains comprise the largest mountain range in arid Central Asia, which is called the "wet island" of Central Asia. The climate of the Tianshan Mountains is dominated by westerly winds and it plays an important role in global climate change research (Huang et al., 2013). It is vital to understand the past climatic changes in this area and to explore possible influence mechanisms regarding the sustainable use of the regional water resources. 
The northern slopes of the Tianshan Mountains in Xinjiang represent a populated area that is undergoing rapid development of agricultural and economic. In northern Xinjiang, the winters are long and cold and $>80 \%$ of the annual precipitation is delivered as snowfall (Li, 1991). Most of the Tianshan Mountains are covered with snow in winter, and the heavy snow, snowstorms, avalanches, and snowmelt floods in spring can bring great economic losses and even threaten human survival. As an indicator of climatic change, snow depth is an interesting variable because it is dependent not only on temperature but also on precipitation (Beniston, 1997). Studies on the long-term snow cover conditions are also justified by the impact that the snow cover has on local climate and hydrology (Falarz, 2004). Snow depth is arguably the most basic and fundamental descriptive feature of surface snow cover. It provides an intuitive measure of the magnitude of a solid-precipitation event and it has societal importance as a water resource, especially under changing climatic conditions (Doesken and Judson, 1997). Understanding the long-term trends of snow depth in the northern Tianshan Mountains is particularly important for the local government and people, because it can provide basic data for accurate resource assessments, estimates of future hydrometeorological disasters, and information for the Xinjiang government regarding disaster prevention. However, few studies have focused on the long-term changes of snow depth (Beniston, 1997; Leathers and Luff, 1997; Laternser and Schneebeli, 2003; Falarz, 2004; Marty and Blanchet, 2012). In most cases, snow records in China are only a few decades in length, which limit long-term climate change research, and therefore proxy data are required for the research of past climate change. Fortunately, there are a large number of Schrenk spruce (Picea schrenkiana Fisch. et Mey) forests at 1700-3200 $\mathrm{m}$ in the Tianshan Mountains. Previous studies have shown that the tree-ring growth of the Schrenk spruce, grown in arid and semiarid mountainous environments, is sensitive to climate and thus is suitable for the reconstruction of past climate change (Li et al., 2006; Zhang et al., 2009, 2013, 2015b, 2016; Chen et al., 2011).

Dendroclimatology is an important method for examining pre-instrumental climatic variations. Because of the precise dating control, annual resolution, and comparability with instrumental meteorological data, tree-ring data have become increasingly valuable in disclosing the longterm dynamics of climate in different regions of the world (Briffa et al., 2001; Esper et al., 2002, 2007; Palmer et al., 2006; Liu et al., 2009; Cook et al., 2010; Shao et al., 2010; Büntgen et al., 2011). However, few studies (e.g., Woodhouse, 2003; Timilsena and Piechota, 2008; Yadav and Bhutiyani, 2013) have reconstructed snow cover using tree-ring chronologies as predictors. In this study, we developed five tree-ring-width chronologies for the northern Tianshan Mountains, analyzed tree-ring response to snow cover and its possible physiological significance, and reconstructed the century annual maximum snow depth of the northern Tianshan Mountains. Finally, the characteristics of the change in annual maximum snow depth over the past hundred years are presented. The purpose of this study is to understand the past century changes of snow cover in northern Tianshan Mountains, it is help for prevent and reduce the meteorological disaster and early warning of natural disasters.

\section{MATERIALS AND METHODS}

\section{Study area}

The study area is located in the southwestern part of the Junggar Basin, and on northern slope of the Tianshan Mountains in Xinjiang Uygur Autonomous Region, northwest of China. The north and west of study area is close the Republic of Kazakhstan. It is a mountainous region that occupies a V-shaped basin between the Dzungarian Alatau to the northwest and the Borohoro Mountains to the southwest. It has a typical continental climate that is dominated by westerly winds. The area is rich in water resources with the Ebi and Sayram lakes, and the Bortala and Jing rivers located on the alluvial plain between the mountains. The water resources are derived from orographic rain and meltwater from the mountains. As part of the Central Asian climate zone, the ecological environment is fragile and it has special status in global climate change research.

\section{Development of tree-ring chronologies}

Trees were sampled according to the standards of the International Tree-Ring Data Bank. The five sites were located in the northern Tianshan Mountains (Fig. 1, Table 1). Samples of Schrenk spruce (Picea schrenkiana Fisch. et Mey) were collected from virgin forests in areas with the harshest conditions. Large replications of samples from the respective sites were used in this study to develop independent site chronologies. In all, 287 tree

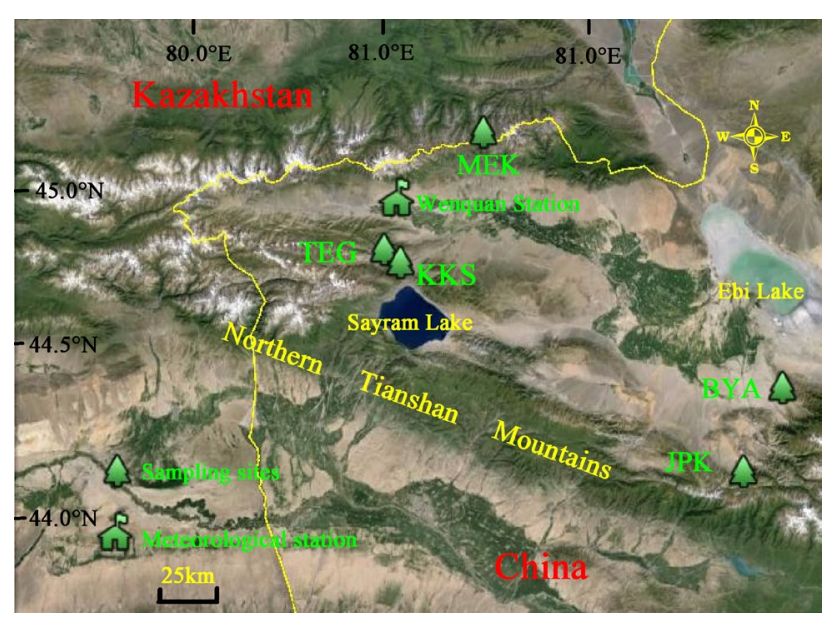

Fig. 1. Locations of tree-ring sampling sites and meteorological station. 
cores from 138 trees were collected from the five sites and used in preparation of the chronologies (Table 1).

All samples (cores) were air-dried, fixed to slotted wooden bars, and then sanded with progressively finer sandpaper up to 600 grit $(16 \mu \mathrm{m})$. Tree-ring widths were measured using a Velmex system (Velmex Inc., Bloomfield, NY, USA), which has an accuracy of $0.001 \mathrm{~mm}$. The tree-ring samples were cross-dated visually and the quality control of the match checked using COFECHA software (Holmes, 1983). Each individual ring-width measurement series was detrended and standardized to ring-width indices using the ARSTAN program (Cook, 1985). Undesirable growth trends related to age and stand dynamics unrelated to climatic variations were removed from each series during the detrending process. We compared three detrending techniques to determine the best method: smoothing spline (fixed 67\% cutoff), regional curve (Cook and Kairiukstis, 1990; Briffa and Melvin,
2011), and negative exponential curve fitting with and without application of an adaptive power transform (Cook and Petersk, 1997). Following these processes, we obtained three types of chronology: the standard chronology, residual chronology, and ARSTAN chronology. We compared the mean sensitivity, standard deviation, signal-to-noise ratio, and expressed population signal of all the chronologies, combined with the tree-ring-width response to climate, and chose smoothing spline (fixed $67 \%$ cutoff) as the most suitable detrending method. Finally, we obtained five standardized chronologies (Fig. 2). Subsample signal strength was used to assess the adequacy of the replication in the early years of the chronology, which can ensure the reliability of the reconstructed climate (Wigley et al., 1984). To use the maximum length of tree-ring chronologies and to ensure the reliability of the reconstructions, we restricted our analysis to the period with subsample signal strength of at least 0.85 (Table 1).

Table 1. Location information and basic chronology statisticsa.

\begin{tabular}{ccccccccc}
\hline Sampling sites & Site & $\begin{array}{c}\text { Location } \\
\left({ }^{\circ} \mathbf{N},{ }^{\circ} \mathrm{E}\right)\end{array}$ & $\begin{array}{c}\text { Elevation } \\
(\mathbf{m} \text { asl) }\end{array}$ & $\begin{array}{c}\text { Trees/Cores } \\
\text { (Available cores }\end{array}$ & $\begin{array}{c}\text { Chronology Interval } \\
\text { SSS>0.85 }\end{array}$ & MS & SD & AR1 \\
\hline Bayinamen & BYA & $44^{\circ} 25^{\prime}, 83^{\circ} 05^{\prime}$ & 1898 & $30 / 60 / 58$ & $1805-2010$ & 0.306 & 0.335 & 0.401 \\
Mirqik Valley & MEK & $45^{\circ} 14^{\prime}, 81^{\circ} 26^{\prime}$ & 2424 & $26 / 52 / 52$ & $1772-2010$ & 0.105 & 0.147 & 0.571 \\
Tuerhong Valley & TEG & $44^{\circ} 46^{\prime}, 81^{\circ} 00^{\prime}$ & 2070 & $27 / 54 / 45$ & $1657-2010$ & 0.379 & 0.391 & 0.408 \\
Kekesay & KKS & $44^{\circ} 44^{\prime}, 81^{\circ} 05^{\prime}$ & 2389 & $27 / 52 / 49$ & $1647-2010$ & 0.151 & 0.246 & 0.740 \\
Jipuke & JPK & $44^{\circ} 06^{\prime}, 82^{\circ} 55^{\prime}$ & 2422 & $28 / 69 / 64$ & $1492-2004$ & 0.241 & 0.243 & 0.329 \\
\hline
\end{tabular}

aThe details of site locations are shown in Fig 1.

MS - mean sensitivity; SD — standard deviation; AR1 — first-order autocorrelation.

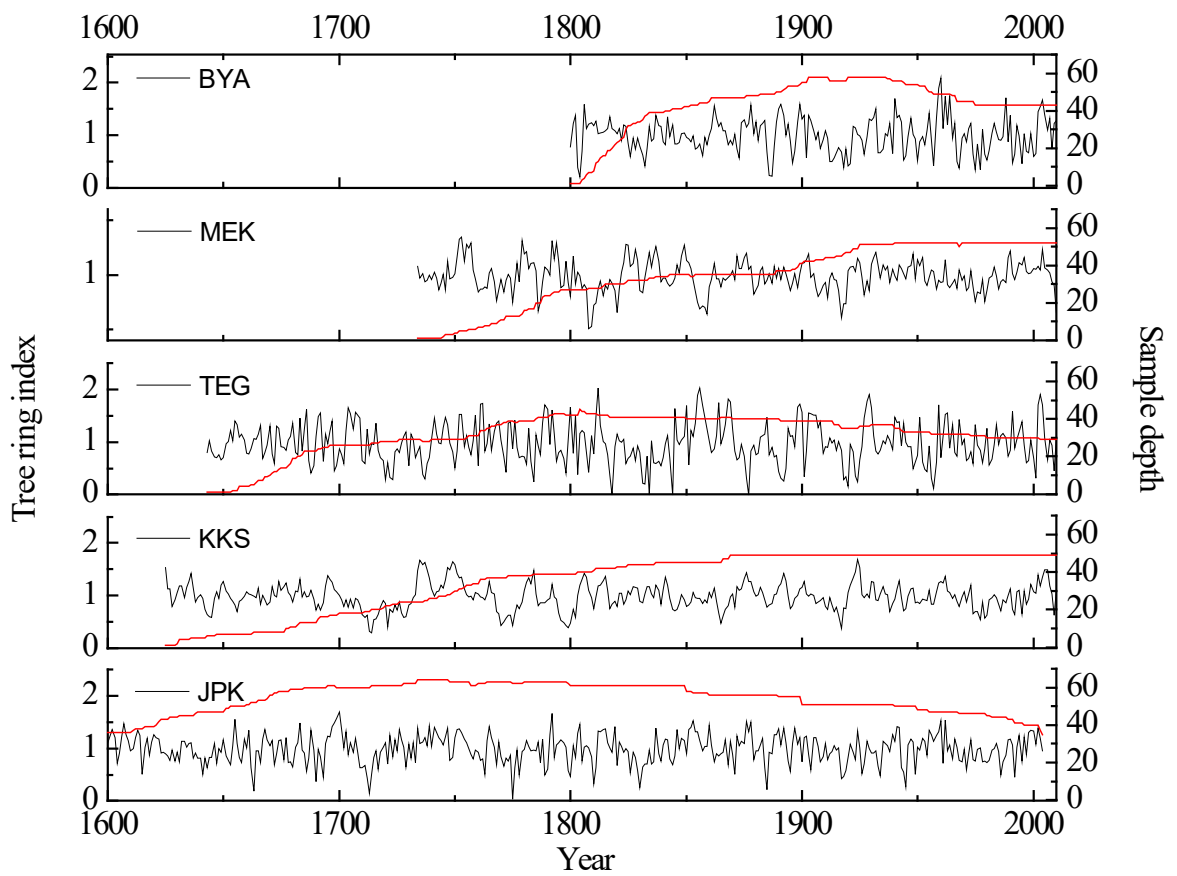

Fig. 2. Tree-ring width chronologies and sample depth from five sample sites in northern Tianshan Mountains. 


\section{Meteorological data}

Meteorological data were obtained from the China Meteorological Data Sharing Service System (http://cdc.cma.gov.cn/). Considering its proximity to the sampling sites, higher elevation, and length of its climate records, we selected snow data from the Wenquan meteorological station $\left(44^{\circ} 58^{\prime} \mathrm{N}, 91^{\circ} 01^{\prime} \mathrm{E}\right.$; elevation: $\left.1354 \mathrm{~m}\right)$. The snow cover parameters included annual maximum snow depth, duration of snow cover $\geq 1 \mathrm{~cm}$, and duration of snow cover $\geq 10 \mathrm{~cm}$ from 1958/1959-2009/10, and the maximum snow pressure from 1986/1987-2009/2010. The study area has typical semiarid temperate continental climate, characterized by arid weather, long durations of sunlight, and large diurnal temperature variations. The annual average temperature is around $3.7-7.4^{\circ} \mathrm{C}$ and the annual precipitation is $234 \mathrm{~mm}$. The trends between maximum snow depth and maximum snow pressure are consistent with the highest values in February (Fig. 3).

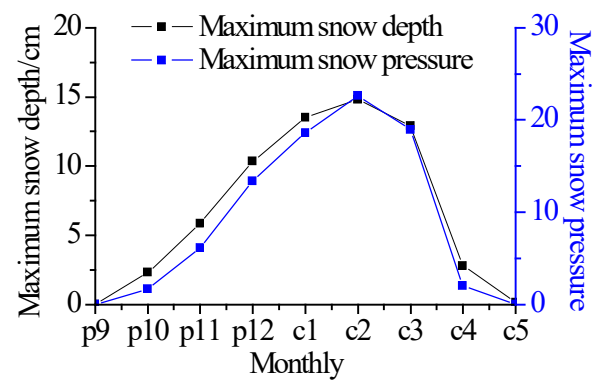

Fig. 3. Monthly snow cover variability of Wenquan meteorological station.

\section{Methods}

The relationship between the tree-ring chronologies and snow cover data was analyzed using DENDROCLIM 2002 (Biondi and Waikul, 2004). All statistical procedures were evaluated at $p<0.05$ level of significance.

Annual maximum snow depth modeling was conducted using the transfer function approach (Fritts, 1976; Cook and Kairiukstis, 1990). Multiple stepwise linear regression was used to develop a linear model to estimate the dependent maximum snow depth variable from a set of potential tree-ring predictors.

The calibration model was evaluated based on the variance in the instrumental record explained by the model ( $\mathrm{R}^{2}$ cal). As the data set from 1958/59-2003/04 was too short for meaningful division into two subsets for calibration and verification purposes (Fritts et al., 1990), the leave-one-out cross-validation method (Michaelsen, 1987) was used to verify our reconstruction. This method calibrates a model based on an iterative process in which each of the predictor values is omitted from the calibra- tion period in turn and then estimated. Verification tests included the reduction of error and sign test (Fritts, 1976).

In a final step, if the developed model passed the verification tests of the previous step, it was applied to the pre-instrumental tree-ring index series to estimate the long-term record of maximum snow depth.

\section{RESULTS AND DISCUSSION}

\section{Tree growth-snow cover relationship}

Table 1 shows the first-order autocorrelations of the five standardized chronologies are higher, and the highest is $>0.7$. It preliminarily indicates that in the northern Tianshan Mountains, radial growth of Schrenk spruce might reflect the effect of climatic factors prior to the growing season. Further analysis shows significant positive correlation between radial growth of Schrenk spruce and snow cover parameters; the best relationship is between maximum snow depth and tree-ring chronologies. The correlation coefficients between the BYA chronology and precipitation in winter is $0.392(p<0.01, n=52)$, between the MEK chronology and duration of snow cover $\geq 10 \mathrm{~cm}$ is $0.433(p<0.01, n=52)$, between the JPK chronology and duration of snow cover $\geq 1 \mathrm{~cm}$ is 0.349 ( $p$ $<0.05, n=46)$, between the TEG chronology and annual maximum snow pressure is $0.602(p<0.01, n=24)$, and between the MEK chronology and annual maximum snow depth is $0.404(p<0.01, n=52)$. Three correlation coefficients of three chronologies (MEK, TEG, and JPK) with annual maximum snow depth are over the $99 \%$ confidence level test, and the highest single correlation is 0.404 (Table 2). Thus, the maximum snow depth might be the principal limiting factor affecting the radial growth of Schrenk spruce trees within the study area.

Fritts (1976) suggested that climatic conditions in autumn, winter, and spring prior to the growing season might affect ring-width growth during the growing period. Snow plays an important role in a number of environmental and socioeconomic systems in mountain regions (Barry, 1992). Similarly, snow cover also has significant impact on the growth of trees in the mountains. The physiological significance of tree-ring response to snow cover is manifested in three ways. First, thicker snow cover can delay spring snowmelt, storing additional water for earlywood growth, which leads to a wider ring. Second, thicker snow cover can increase soil moisture content, compensating water loss caused by drought in spring. Water deficit in the early stages of the growing season suppresses rapid expansion of tracheids and cell division in the cambium of trees (Fritts, 1976; Akkemik, 2003). Many studies have shown that greater snowfall during the non-growth season means trees might absorb more moisture in the early part of the growing season (D'Arrigo and Jacoby, 1991; Diaz et al., 2002). Third, thicker snow cover plays an insulating role in keeping the temperature constant. A higher temperature might benefit the radial growth of spruce trees during the growing sea- 
L. Qin et al.

Table 2. Pearson Correlation between tree-ring chronologies and snow cover parameters.

\begin{tabular}{clllll}
\hline & BYA & MEK & TEG & KKS & JPK \\
\hline $\begin{array}{c}\text { Maximum snow depth } \\
(1958 / 59-2009 / 10)\end{array}$ & $\mathbf{0 . 3 3 9 ^ { * }}$ & $\mathbf{0 . 4 0 4 ^ { * * }}$ & $\mathbf{0 . 3 8 7 ^ { * * }}$ & $\mathbf{0 . 2 6 0}$ & $\mathbf{0 . 3 9 0 ^ { * * }}$ \\
\hline $\begin{array}{c}\text { Maximum snow pressure } \\
(1986 / 87-2009 / 10)\end{array}$ & 0.298 & $0.443^{*}$ & $0.602^{* *}$ & 0.298 & 0.242 \\
\hline $\begin{array}{c}\text { Duration of } \geq 1 \text { cm depth } \\
(1958 / 59-2009 / 10)\end{array}$ & 0.205 & 0.246 & $0.293^{*}$ & 0.135 & $0.349^{*}$ \\
\hline $\begin{array}{c}\text { Duration of } \geq 10 \mathrm{~cm} \text { depth } \\
(1958 / 59-2009 / 10)\end{array}$ & $0.295^{*}$ & $0.433^{* *}$ & $0.308^{*}$ & 0.246 & $0.314^{*}$ \\
\hline $\begin{array}{c}\text { Precipitation in winter } \\
(1958 / 59-2009 / 10)\end{array}$ & $0.392^{* *}$ & $0.345^{*}$ & 0.075 & $0.375^{*}$ & 0.276 \\
\hline
\end{tabular}

** - indicate significance at the $99 \%$ level of confidence.

* - indicate significance at the $95 \%$ level of confidence.

son because the growing season is advanced and there may be less winter damage to the shallow roots of the spruce trees (Liang et al., 2006; Zhang et al., 2015a). A study by Vaganov et al. (1999) showed that winter precipitation (snow cover) has a clearly positive trend with radial growth. Because winter precipitation shifts the onset of cambial activity to later dates, this leads to later activation of tree growth. Furthermore, the greater the amount of winter precipitation is, the greater its influence. Snow cover is a uniquely sensitive climate variable, which depends on temperature and precipitation at a variety of temporal and spatial scales (Marty and Blanchet, 2012). Tree-ring response to snow cover might indicate that comprehensive and complex signals of winter climate affect radial tree growth. Therefore, tree-rings can be considered as good indicators of snow cover variability in the northern Tianshan Mountains, which have physiological significance.

\section{Maximum snow depth reconstruction and validation}

The correlation and response analysis showed a high correlation coefficient between the five standardized treering chronologies and maximum snow depth at the Wenquan station. Based on the results, the maximum snow depth was reconstructed and a transfer function designed as follows:

$$
\begin{aligned}
\mathrm{SD}_{\max }= & 5.3 \times \mathrm{TEG}+9.3 \times \mathrm{JPK}+26.7 \times \mathrm{MEK}+ \\
& 8.1 \times \mathrm{BYA}-21.5 \times \mathrm{KKS}-11.3
\end{aligned}
$$

where $\mathrm{SD}_{\max }$ is the maximum snow depth and TEG, JPK, MEK, BYA, and KKS are the five standard chronologies in the northern Tianshan Mountains. During the calibration period (1959-2004), the reconstruction tracks the observations well, with the explained variance of $48.3 \%$ (41.8\% after adjustment for loss of degrees of freedom) of the observed maximum snow depth data. In model (3.1), $n=46, r=0.695, F_{5,40}=7.5$ and $p<0.0001$. In this study, the Durbin-Watson value (Durbin and Watson, 1951) was 2.394 for $n=46$, which indicates no significant first-order autocorrelation in model (3.1). During the calibrated period (1958/59-2003/04), the reconstructed maximum snow depth data tracks the observations very well (Fig. 4). Thus, the reconstruction might be able to reveal the maximum snow depth variability over the past 194 years in the northern Tianshan Mountains.

The model passed all the verification tests (Table 3). The cross-validation test yielded a positive reduction of error (0.316), thus indicating the predictive skill of the regression model. The statistically significant sign test $\left(36+, 10^{-}, p<0.01\right)$ and correlation $(r=0.577, p<0.01)$, and first difference sign test $(31+, 14-, p<0.05)$ and correlation $(r=0.408, p<0.01)$, between the maximum snow depth data and the estimates derived from the leaveone-out method, are also indications of the validity of the reconstruction. Therefore, this equation can reconstruct the annual maximum snow depth from 1810-2004 in the northern Tianshan Mountains (Fig. 4). Fig. 4 also shows the annual maximum snow depth during the calibrated period from 1959-2004.

\section{Characteristics of maximum snow depth over the past two centuries}

The high-frequency variability of the maximum snow depth series over the past $195 \mathrm{yr}$ in the northern Tianshan Mountains is within the range of $0.9-27.9 \mathrm{~cm}$; for which the mean square deviation is 0.384 . We obtained the lowfrequency variability of the maximum snow depth series using the 20-yr low-pass filter method (Fig. 4). The lowfrequency change is within the range of $8.2-21.9 \mathrm{~cm}$; for which the mean square deviation is 0.210 . The reconstructed series shows that maximum snow depth exhibits

Table 3. Statistical crossing-test characters of the equations reconstructed.

\begin{tabular}{lcccccc}
\hline & $\mathbf{r}$ & $\mathbf{r}_{\mathbf{d}}$ & $\mathbf{z}$ & $\mathbf{z}_{\mathbf{d}}$ & $\mathbf{t}$ & $\boldsymbol{R E}$ \\
\hline $\begin{array}{l}\text { Maximum snow } \\
\text { depth }\end{array}$ & $0.577^{* *}$ & $0.408^{* *}$ & $10 / 46^{* *}$ & $14 / 45^{*}$ & $7.559^{* *}$ & 0.316 \\
\hline ** - indicate significance at the $99 \%$ level of confidence. & \\
* - indicate significance at the $95 \%$ level of confidence.
\end{tabular}




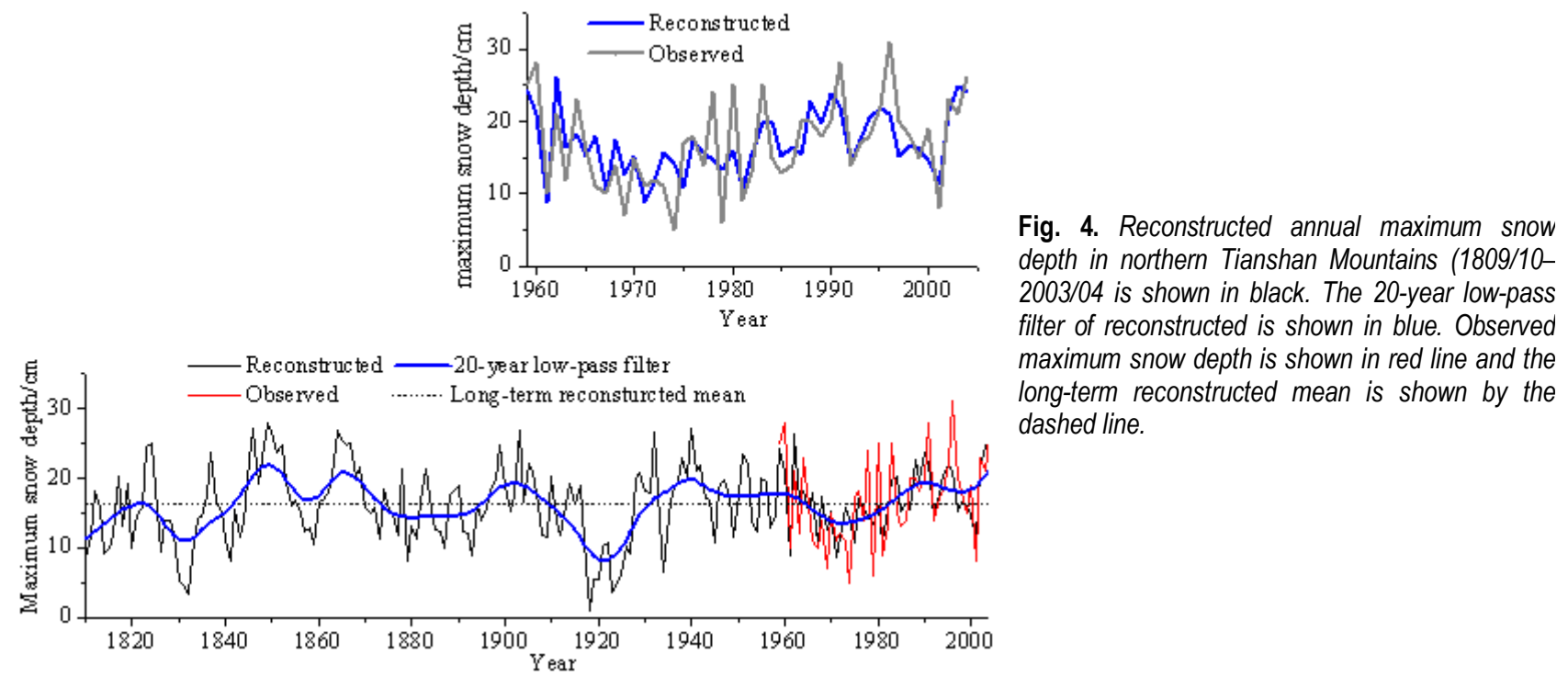

obvious stages change, the periods characterized by lower maximum snow depth were 1809/10-1840/41, 1873/74 1893/94, 1909/10-1929/30, 1964/65-1981/82, and the periods characterized by higher maximum snow depth were $1841 / 42-1872 / 73,1894 / 95-1908 / 09, \quad 1930 / 31-$ $1963 / 64$, and 1982/83-present. Because of the lack of studies on snow cover variability over the past $200 \mathrm{yr}$ in the Tianshan Mountains, we compared the changes of the maximum snow depth with historical periods of precipitation and drought. A study by Zhang et al. (2015b) showed that the July-June precipitation of the western Tianshan Mountains in 1829-1842, 1881-1892, 19161928, and 1935-1982 was relatively less. These drought periods are remarkably consistent with the periods of lower maximum snow depth in our results. In addition, the four lower periods are consistent with the drought variability at the Asian summer monsoon fringe, particularly the two severe drought periods (Yang et al., 2014).

With regard to decadal changes, the decade with the highest maximum snow depth is the 1860 s with an average value of $21.5 \mathrm{~cm}(+32.7 \%)$. The decade with lowest maximum snow depth is the 1920 s with an average value of $10.2 \mathrm{~cm}(+37.4 \%)$ (Fig. 5), and this decade is consistent with the drought of the 1920s in northern China. The study by Liang et al. (2006) showed that a severe and sustained drought occurred in the 1920s and early 1930s, which was confirmed by tree rings and a variety of historical and instrumental records including hydrological, meteorological, and documentary evidence from the semiarid and arid areas of northern China. Fang et al. (2012) suggested the aridity that occurred in the 1920s1930s was most severe in northern China. Li et al. (2006) showed that the late 1920s was the epoch with the most severe drought in the reconstruction of northern central
China. From the 1970s to the present, the maximum snow depth has clearly increased with the change to a warmer and wetter climate in Xinjiang.

Strong interannual variability of the maximum snow depth was identified in the northern Tianshan Mountains by Thomson (1982) using the multi-taper method. There are significant changes of the annual maximum snow depth at 2.0-yr (99\%), 2.2-yr (99\%), 2.8-yr (95\%), 3.5$3.8-\mathrm{yr}(99 \%), 5.3-\mathrm{yr}(95 \%), 14.0-\mathrm{yr}(95 \%)$, and 36.0-yr (95\%) cycles (Fig. 6). Most of these interannual cycles $(5.3,3.5-3.8,2.8,2.2$, and $2.0 \mathrm{yr})$ in our reconstruction fall within the range of the El Niño Southern Oscillation (Allan et al., 1996). In addition, the 2-3-yr cycle that can also be identified in arid Central Asia (Huang et al., 2013), is linked to variations of the westerly circulation in the middle troposphere, which may indicate that our reconstructed maximum snow depth variability might have some teleconnections with oscillations of the landatmosphere-ocean circulation systems. Furthermore, these high-frequency cycles can often be found in den-

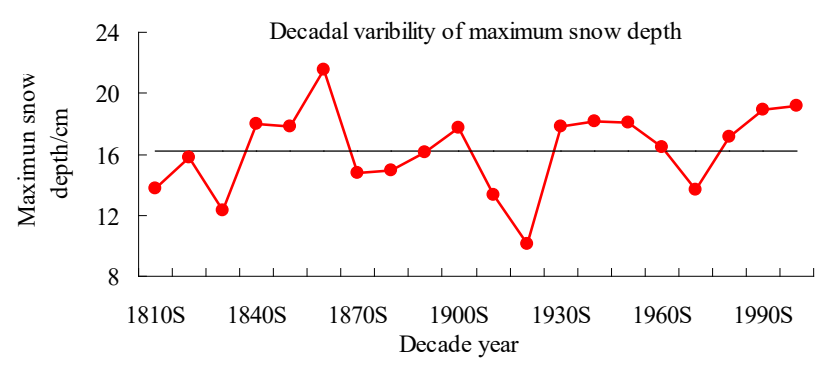

Fig. 5. Decade change of maximum snow depth in northern Tianshan Mountains. 


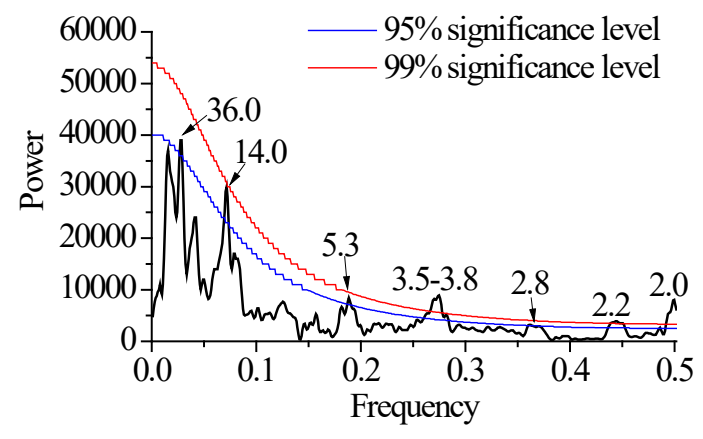

Fig. 6. Multi-Taper Power spectra for the reconstructed annual maximum snow depth (AD 1800-2010). Peaks above the blue line indicate significance at the $95 \%$ level of confidence and Peaks above the red line indicate significance at the $99 \%$ level of confidence.

droclimatic studies of the Tianshan Mountains (e.g., Li et al., 2006; Zhang et al., 2009, 2013, 2015b, 2016) and other arid and semiarid sites in northwestern China (Liang et al., 2009; Chen et al., 2011; Liu et al., 2011). The decadal-scale cycles of $14.0 \mathrm{yr}$ falls within the range of the Pacific Decadal Oscillation (Minobe, 1997; Mantua and Hare, 2002) and Atlantic Multidecadal Oscillation (Gray et al., 2004; Mann et al., 2009). The lowfrequency peak (36-yr) is obviously consistent with periodic solar activity. In terms of climatic change, cycles with a length of $36 \mathrm{yr}$ are not new. Brückner (1890) demonstrated that varied climatic phenomena in different regions of the world show phase synchronism with cycles of 33-37 yr and surmised connections with solar activity. This suggests that the maximum snow depth variability of the northern Tianshan Mountains might be related to large-scale oscillation of the climate system.

\section{CONCLUSIONS}

We developed five tree-ring chronologies from 268 spruce trees sampled in the northern Tianshan Mountains. The tree growth-snow cover responses were analyzed in combination with snow cover data. It was found that maximum snow depth is the principal limiting factor that affects the radial growth of Schrenk spruce trees within the study area. Analysis showed that tree-ring response to snow has physiological significance. Hence, we reconstructed the century annual maximum snow depth for the northern Tianshan Mountains. This indicated that quasiperiodic changes exist on scales of 2.0-4.0,5.3, 14.0, and 36.0 yr. The lower period of annual maximum snow depth during the 1920s-1930s is consistent with the severe drought that occurred in the 1920s and early 1930s in northern China. From the 1970s to the present, the maximum snow depth has clearly increased with the warmer and wetter climate in Xinjiang. We suggest future work could investigate links with the drought mechanisms of northern China when considering mechanisms of snow variability.

\section{ACKNOWLEDGMENTS}

This study was supported by Key Laboratory of Xinjiang Uygur Autonomous Region Project (2015KL017), National Natural Science Foundation of China Projects (41271098, 41405139) and Meteorology Public Welfare Industry Research Special Project (GYHY201206014). Sincerely thank the reviewers and the editor for constructive comments and suggestions that improved the quality of the paper.

\section{REFERENCES}

Akkemik Ü, 2003. Tree rings of Cedrus libani at the northern boundary of its natural distribution. IAWA Journal 24: 63-73, DOI 10.1163/22941932-90000321.

Allan R, Lindesay J and Parker D, 1996. El Niño: Southern Oscillation and Climatic Variability. CSIRO Publishing, Collinwood.

Barry RG, 1992. Mountain Climatology and Past and Potential Future Climatic Changes in Mountain Regions: A Review. Mountain Research and Development 12: 71-86, DOI 10.2307/3673749.

Beniston M, 1997. Variations of snow depth and duration in the Swiss Alps over the last 50 years: links to changes in large-scale climatic forings. Climatic Change 36: 281-300, DOI 10.1023/A:1005310214361.

Biondi F and Waikul K, 2004. Dendroclim2002: A C ++ program for statistical calibration of climate signals in tree-ring chronologies. Computers and Geosciences 30: 303-311, DOI 10.1016/j.cageo.2003.11.004.

Briffa KR, Osborn TJ, Schweingruber FH, Harris IC, Jones PD, Shiyatov SG and Vaganov EA, 2001. Low-frequency temperature variations from a northern tree ring density network. Journal of Geophysical Research 106: 2929-2941, DOI 10.1029/2000JD900617.

Briffa KR and Melvin TM, 2011. A closer look at Regional Curve Standardisation of tree-ring records: justification of the need, a warning of some pitfalls, and suggested improvements in its application. In: Hughes MK, Diaz HF and Swetnam TW (Eds.), Dendroclimatology: Developments in Paleoenvironmental Research 11: 113-145.

Brückner E, 1890. Klima-schwankungen seit 1700, nebst bemerkungen über die klimaschwankungen der diluvialzeit (Climatic change since 1700 , including recorded on climatic change during the the Diluvial period). Geographische Abhandlungen 14: 325 (in German)

Büntgen U, Tegel W, Nicolussi K, McCormick M, Frank D, Trouet V, Kaplan JO, Herzig F, Heussner KU, Wanner H, Luterbacher J and Esper J, 2011. 2500 years of European climate variability and human susceptibility. Science 331: 578-582, DOI 10.1126/science.1197175.

Chen F, Yuan YJ and Wei WS, 2011. Climatic response of Picea crassifolia tree-ring parameters and precipitation reconstruction in the western Qilian Mountains, China. Journal of Arid Environments 75: 1121-1128, DOI 10.1016/j.jaridenv.2011.06.010.

Cook ER, 1985. A Time-series Analysis Approach to Tree-ring Standardization. $\mathrm{PhD}$ dissertation, University of Arizona.

Cook ER, Anchukaitis KJ, Buckley BM, D'Arrigo RD, Jacoby GC and Wright WE, 2010. Asian monsoon failure and megadrought during the last millennium. Science 328: 486-489, DOI 10.1126/science. 1185188 .

Cook ER and Kairiukstis LA, 1990. Methods of Dendrochronology: Applications in the Environmental Sciences. Kluwer Academic Publishers, Boston, Massachusetts.

Cook ER and Peters K, 1997. Calculating unbiased tree-ring indices for the study of climatic and environmental change. Holocene 7 : 361370, DOI 10.1177/095968369700700314.

D'Arrigo RD and Jacoby GC, 1991. A 1000-year record of winter precipitation from northwestern New Mexico, USA: a reconstruction from tree-rings and its relation to El Nĩno and the Southern 
Oscillation. Holocene 1: 95-101, DOI 10.1177/095968369100100201.

Diaz SC, Therrell MD, Stahle DW and Cleaveland MK, 2002. Chihuahua (Mexico) winter-spring precipitation reconstructed from treerings, 1647-1992. Climate Research 22: 237-244, DOI $10.3354 / \mathrm{cr} 022237$

Doesken NJ and Judson A, 1997. The Snow Booklet - A guide to the science, climatology, and measurement of snow in the United States. Fort Collins, CO: Colorado State University.

Durbin J and Watson GS, 1951. Testing for serial correlation in least squares regression. Biometrika 38: 159-178.

Esper J, Cook ER and Schweingruber FH, 2002. Low-frequency signals in long tree-ring chronologies for reconstructing past temperature variability. Science 295: 2250-2253, DOI 10.1126/science.1066208.

Esper J, Frank DC, Büntgen U, Verstege A, Luterbacher J and Xoplaki E, 2007. Long-term drought severity variations in Morocco. Geophysical Research Letters 34: L17702, DOI 10.1029/2007GL030844.

Falarz M, 2004. Variability and trends in the duration and depth of snow cover in Poland in the $20^{\text {th }}$ century. International Journal of Climatology 24: 1713-1727, DOI 10.1002/joc.1093.

Fang KY, Gou XH, Chen FH, Liu CZ, Davi N, Li JB, Zhao ZQ and Li YJ, 2012. Tree-ring based reconstruction of drought variability (1615-2009) in the Kongtong Mountain area, northern China. Global and Planetary Change 80-81: 190-197, DOI 10.1016/j.gloplacha.2011.10.009.

Fritts HC, 1976. Tree rings and climate. Academic Press, Inc. (London), Ltd., New York, 565.

Fritts HC, Guiot J and Gordon GA, 1990. Verification. In: Cook, E.R., Kairiukstis, L.A.(Eds.). Methods of Dendrochronology: Applications in the Environmental Sciences. Kluwer, London, 178-185.

Gray ST, Graumlich LJ, Betancourt JL and Pederson GT, 2004. A treering based reconstruction of the Atlantic Multidecadal Oscillation since 1567 A.D. Geophysical Research Letters 31: L12205, DOI 10.1029/2004GL019932.

Holmes RL, 1983. Computer-assisted quality control in tree-ring dating and measurement. Tree-Ring Bulletin 43: 69-75.

Huang W, Chen FH, Feng S, Chen JW and Zhang XJ, 2013. Interannual precipitation variations in the mid-latitude Asia and their association with large-scale atmospheric circulation. Chinese Science Bulletin 58: 3962-3968, DOI 10.1007/s11434-013-5970-4.

Laternser M and Schneebeli M, 2003. Long-term snow climate trends of the Swiss Slps (1931-99). International Journal of Climatology 23: 733-750, DOI 10.1002/joc.912.

Leathers DJ and Luff BL, 1997. Characteristics of snow cover duration across the northeast United States of America. Intemational Journal of Climatology 17: 1535-1547, DOI 10.1002/(SICI)10970088(19971130)17:14<1535::AID-JOC215>3.0.CO;2-7.

Li JB, Chen FH, Cook ER, Gou XH and Zhang YX, 2006. Drought reconstruction for north central China from tree rings: the value of the Palmer drought severity index. Intemational Journal of Climatology 27: 903-909, DOI 10.1002/joc.1450.

Li JB, Gou XH, Cook ER and Chen FH, 2006. Tree-ring based drought reconstruction for the central Tien Shan area in northwest China. Geophysical Research Letters 33: L07715, DOI 10.1029/2006GL025803.

Li JF, 1991. Xinjiang climate. Beijing: Meteorological Press 115-124. (in Chinese)

Liang EY, Liu XH, Yuan YJ, Qin NS, Fang XQ, Huang L, Zhu HF, Wang LL and Shao XM, 2006. The 1920 drought recorded by tree rings and historical documents in the semi-arid and areas of northern China. Climatic Change 79: 403-432, DOI 10.1007/s10584006-9082-x.

Liang EY, Shao XM and Liu XH, 2009. Annual precipitation variation inferred from tree rings since A.D. 1770 for the western Qilian Mts., Northern Tibetan Plateau. Tree-Ring Research 65: 95-103, DOI 10.3959/2008-2.1.

Liu Y, An ZS, Linderholm HW, Chen DL, Song HM, Cai QF, Sun JY and Tian H, 2009. Annual temperatures during the last 2485 years in the mid-eastern Tibetan Plateau inferred from tree rings. Science in China Series D: Earth Sciences 52: 348-359, DOI 10.1007/s11430-009-0025-Z

Liu Y, Wang CY, Hao WJ, Song HM, Cai QF, Tian H, Sun B and Linderholm HW, 2011. Tree-ring-based annual precipitation reconstruction in Kalaqin, Inner Mongolia for the last 238 years. Chinese Science Bulletin 56: 2995-3002, DOI 10.1007/s11434011-4706-6.

Mann ME, Zhang ZH, Rutherford S, Bradley RS, Hughes MK, Shindell D, Ammann C, Faluvegi G and Ni FB, 2009. Global signatures and dynamical origins of the Little Ice Age and Medieval Climate Anomaly. Science 326: 1256-1260, DOI 10.1126/science. 1177303

Mantua NJ and Hare SR, 2002. The Pacific Decadal Oscillation. Journal of Oceanography 58: 35-44, DOI 10.1023/A:1015820616384.

Marty $\mathrm{C}$ and Blanchet J, 2012. Long-term changes in annual maximum snow depth and snowfall in Switzerland based on extreme value statistics. Climatic Change 111: 705-721, DOI 10.1007/s10584011-0159-9.

Michaelsen J, 1987. Cross-validation in statistical climate forecast models. Journal of Applied Meteorology 26: 1589-1600, DOI 10.1175/1520-0450(1987)026<1589:CVISCF $>2.0 . C O ; 2$.

Minobe S, 1997. A 50-70 year climate oscillation over the North Pacific and North America. Geophysical Research Letters 24: 683-686, DOI 10.1029/97GL00504.

Palmer J, Lorrey A, Turney CSM, Hogg A, Baillie M, Fifield K and Ogden J, 2006. Extension of New Zealand kauri (Agathis australis) tree-ring chronologies into Oxygen Isotope Stage (OIS) 3. Journal of Quaternary Science 21: 779-787, DOI 10.1002/jqs.1075.

Shao X, Xu Y, Yin ZY, Liang EY, Zhu HF and Wang S, 2010. Climatic implications of a 3585-year tree-ring width chronology from the northeastern Qinghai-Tibetan Plateau. Quaternary Science Reviews 29: 2111-2122, DOI 10.1016/j.quascirev.2010.05.005.

Thomson DJ, 1982. Spectrum estimation and harmonic analysis. Proc IEEE 70: 1055-1096, DOI 10.1109/PROC.1982.12433.

Timilsena J and Piechota T, 2008. Regionalization and reconstruction of snow water equivalent in the upper Colorado River basin. Journal of Hydrology 352: 94-106, DOI 10.1016/j.jhydrol.2007.12.024

Vaganov EA, Kirdyanov AV, Schweingruber FH and Silkin PP, 1999. Influence of snowfall and melt timing on tree growth in subarctic Eurasia. Nature 400: 149-151, DOI 10.1038/22087.

Wigley TML, Briffa KR and Jones PD, 1984. On the average value of correlated time series, with application in dendroclimatology and hydrometeorology. Journal of Climate and Applied Meteorology 23: 201-213, DOI $10.1175 / 1520$ 0450(1984)023<0201:OTAVOC $>2.0 . C O ; 2$.

Woodhouse CA, 2003. A 431-yr reconstruction of western Colorado snowpack from tree rings. Journal of Climate 16: 1551-1561.

Yadav RR and Bhutiyani MR, 2013. Tree-ring-based snowfall record for cold arid western Himalaya, India since A.D. 1460. Journal of Geophysical Research: Atmospheric 118: 7516-7522, DOI 10.1002/jgrd.50583.

Yang B, Kang SY, Ljungqvist FC, He MH, Zhao Y and Qin C, 2014. Drought variability at the northern fringe of the Asian summer monsoon region over the past millennia. Climate Dynamics 43(3): 845-859, DOI 10.1007/s00382-013-1962-y.

Zhang RB, Wei WS, Yuan YJ, Yu SL and Yang Q, 2009. A precipitation series of A.D. 1396-2005 in Aksu River Basin on the southern slopes of Tianshan Mountains: reconstruction and analysis. Journal of Glaciology and Geocryology 31: 27-33 (in Chinese, with English abstract)

Zhang RB, Yuan YJ, Wei WS, Gou XH, Yu SL, Shang HM, Chen F, Zhang TW and Qin L, 2015a. Dendroclimatic reconstruction of autumn-winter mean minimum temperature in the eastern Tibetan Plateau since 1600 AD. Dendrochronologia 33: 1-7, DOI 10.1016/j.dendro.2014.09.001.

Zhang TW, Yuan YJ, Liu Y, Wei WS, Yu SL, Chen F, Fan ZA, Shang HM, Zhang RB and Qin L, 2013. A tree ring based precipitation reconstruction for the Baluntai region on the southern slope of the central Tien Shan Mountains, China, since A.D. 1464. Quaternary International 283: 55-62, DOI 10.1016/j.quaint.2012.03.037. 
Zhang TW, Zhang RB, Yuan YJ, Gao YQ, Wei WS, Diushen M, He Q, Shang HM and Wang J, 2015b. Reconstructed precipitation on a centennial timescale from tree rings in the western Tien Shan Mountains, Central Asia. Quaternary International 358: 58-67, DOI 10.1016/j.quaint.2014.10.054.
Zhang RB, Yuan YJ, Gou XH, He Q, Shang HM, Zhang TW, Chen F, Ermenbaev B, Yu SL, Qin L, Fan ZA, 2016. Tree-ring-based moisture variability in western Tianshan Mountains since A.D. 1882 and its possible driving mechanism. Agricultural and Forest Meteorology 218-219: 267-276, DOI 10.1016/j.agrformet.2015.12.067. 